\title{
A CPAT Simulation Analysis on the Effect of Islanding Protection under Clustered PV Application 500 PV Systems
}

\author{
Shuichi Shibata Member (Electric Power Engineering Systems Co., Ltd., shibata@ dentec.co.jp) \\ Kazuya Miyanami Member (Electric Power Engineering Systems Co., Ltd., miyanami@dentec.co.jp) \\ Kiyoshi Takigawa Member (Electric Power Engineering Systems Co., Ltd., takigawa@dentec.co.jp) \\ Hiroyuki Sugihara Member (Kandenko Co., Ltd., sugihara-h01@kandenko.co.jp)
}

Keywords: PV system, clustered installation, islanding protection, simulation analysis

Since the FY2003, the demonstration site Josai-no-mori including over 500 residences with PV system has been under construction at the Ota City, Gunma prefecture. It is important to clear the safety of the islanding protection. However, it is very difficult to verify the islanding phenomena including many PV systems on the actual utility grid, where the people are leading life actually. Therefore, it becomes important to develop a technique employing simulation analysis for the safety evaluation.

Purpose of our study is to clear the details of dangerous islanding phenomena and the effects of various protection methods under clustered installation of over $500 \mathrm{PV}$ systems within a partial area of utility grid. To solve these problems, a new analysis method has been developed, that is based on the CRIEPI's Power system Analysis Tools (CPAT) technology implemented by CRIEPI, so called "Y-method".

As a conventional analysis method of the islanding phenomena, EMTP has been generally applied so far. However, EMTP method based on the instantaneous value analysis has a severe restriction to the applicable number of PV systems and computation speed. The new method is based on the effective value analysis, and has a capability of large scale and high-speed computation by a personal computer. The applicable number of PV units compared with the conventional EMTP method (Table 1). It is one of merits in this model that PV system is expressed briefly as the constant current source equipped with the islanding protection. The number of applicable PV systems was extended to 500.

Figuer 1 show the image of whole Analysis model of demonstration site. Table 2 shows distribution of Grid-connected PCSs at the Demonstration Site. Figure 2 shows variations of line voltage and frequency at the entrance of housing complex on the islanding condition simulated by CPAT. On the active islanding protection, when the function of phase synchronization was equipped, the variation both of line voltage and frequency amplify by strengthening each other. On the other hand, when the function of phase synchronization was not equipped, the variation both of line voltage and frequency become small by denying each other. It has been verified that newly proposed analysis method using CPAT has a capability that can expand to the large scale clustered installation model including many PV systems on a utility grid.

A new simulation method based on CPAT was successfully developed. It has ability of high-speed simulation analysis, for the utility grid including $500 \mathrm{PV}$ systems. As a result, it was verified that a total required computation time on $500 \mathrm{PV}$ systems by the proposed method was within 100 seconds.
Table 1. Comparison of performance for islanding analysis by CPAT and EMTP

\begin{tabular}{|c|c|c|c|c|}
\hline \multirow{2}{*}{} & \multirow{2}{*}{$\begin{array}{c}\text { Resolution of } \\
\text { Frequency }\end{array}$} & \multirow{2}{*}{$\begin{array}{c}\text { Number of } \\
\text { Applicable PV } \\
\text { Systems }\end{array}$} & \multicolumn{2}{|c|}{$\begin{array}{c}\text { Required Time } \\
\text { for Analysis [s] }\end{array}$} \\
\cline { 4 - 5 } & & 30 units & 500 units \\
\hline CPAT & $50 \mathrm{~Hz}$ & 500 units & 18.6 & 99.3 \\
\hline EMTP & $50 \mathrm{kHz}$ & 30 units & 25.0 & N/A \\
\hline
\end{tabular}

A Housing Complex

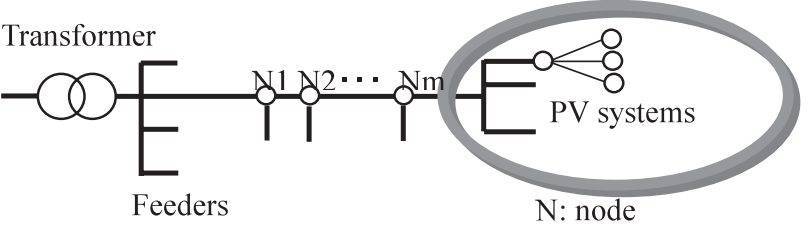

Fig. 1. Analysis model of demonstration site

Table 2. Distribution of grid-connected PCSs at the demonstration site (FY2005)

\begin{tabular}{|c|c|c|c|c|c|c|}
\hline $\begin{array}{c}\text { PCS } \\
\text { model }\end{array}$ & $\begin{array}{c}3.0 \\
{[\mathrm{~kW}]}\end{array}$ & $\begin{array}{c}3.3 \\
{[\mathrm{~kW}]}\end{array}$ & $\begin{array}{c}4.0 \\
{[\mathrm{~kW}]}\end{array}$ & $\begin{array}{c}4.5 \\
{[\mathrm{~kW}]}\end{array}$ & $\begin{array}{c}5.0 \\
{[\mathrm{~kW}]}\end{array}$ & Total \\
\hline A & 10 & - & 46 & - & - & 56 \\
\hline C & - & - & 54 & - & - & 54 \\
\hline D & 18 & - & 2 & 28 & - & 48 \\
\hline E & - & 48 & - & - & 8 & 56 \\
\hline $\begin{array}{c}\text { G\&H with } \\
\text { battery }\end{array}$ & - & - & 130 & - & - & 130 \\
\hline Total & 28 & 48 & 232 & 28 & 8 & 344 \\
\hline
\end{tabular}

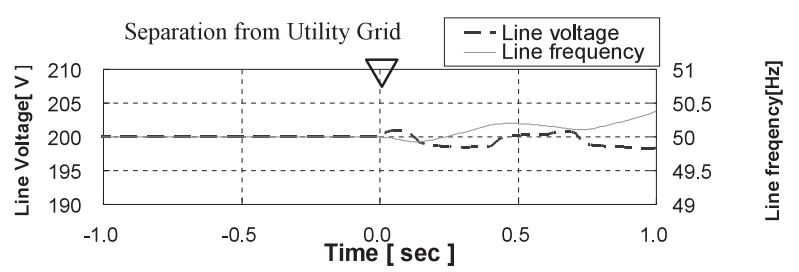

(a) Phase synchronized reactive power variation and frequency shift

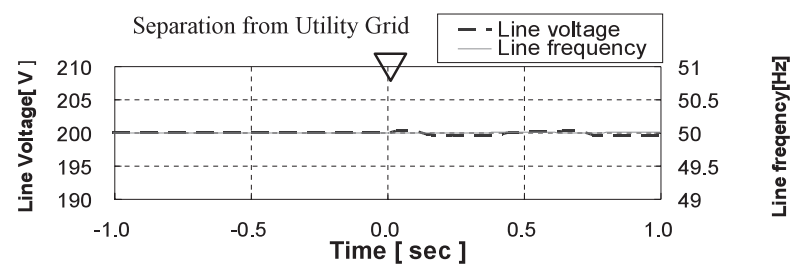

(b) Phase random reactive power variation and frequency shift

Fig. 2. Line voltage and frequency of clustered installation by new simulation method (344 PV systems) 


\title{
500 台規模太陽光発電システム集中連系時の 単独運転検出機能のY法解析手法
}

\author{
正 員 柴田 秀一* 正 員 宮南 一也* \\ 正員 滝川 清* 正員杉原 裕征**
}

\section{A CPAT Simulation Analysis on the Effect of Islanding Protection under Clustered PV Application 500 PV Systems}

Shuichi Shibata*, Member, Kazuya Miyanami*, Member, Kiyoshi Takigawa*, Member, Hiroyuki Sugihara**, Member

Since the FY2003, the demonstration site Josai-no-mori including over 500 residences with PV system has been under construction at the Ota City, Gunma prefecture in Japan. It is important to clear the safety of islanding protection. However, it is very difficult to verify the islanding phenomena including many PV systems on the actual utility grid, where the people are leading life actually. Therefore, it becomes important to develop a technique employing simulation analysis for the safety evaluation.

Purpose of our study is to clear the details of dangerous islanding phenomena and the effects of various protection methods under clustered installation of over $500 \mathrm{PV}$ systems within a partial area of utility grid. To solve these problems, a new analysis method has been developed, that is based on the CRIEPI's Power system Analysis Tools (CPAT) technology implemented by CRIEPI, so called "Y-method".

As a noteworthy result, it has been confirmed that the new simulation method has a capability to expand to the large-scale clustered installation model including 500 PV systems on utility grid. The validity of simulation analysis has been verified by comparing with preliminary indoor tests. In addition, it has been clarified that the combination of passive and active protection methods is very effective to avoid the islanding phenomena.

キーワード：太陽光発電システム，集中連系，単独運転検出，Y 法解析

Keywords: PV system, clustered installation, islanding detection, simulation analysis

\section{1. はじめに}

2003 年以来, 500 台を超える太陽光発電（以下 PV) シ ステムを含む住宅団地「城西の杜」の建設が進められてい る。このように配電線に多数の PV システムが集中連系さ れた状況では, 安全性確保の面から単独運転の防止が重要 な課題である ${ }^{(1) \sim(3)}$ 。単独運転とは配電線が何らかの原因で 電力系統から切離された際に, PV システム群が配電線負 荷を背負って運転継続し, 配電線に電圧を供給し続ける危 険な現象である。PV システムでは一般にパワーコンディ

\footnotetext{
*(株) 電力テクノシステムズ 技術統括部

干 157-0066 東京都世田谷区成城 6-16-3

Electric Power Engineering Systems Co., Ltd.

6-16-3, Seijo, Setagaya-ku, Tokyo 157-0066

** (株) 関電工

干 108-8533 東京都港区芝浦 4-8-33

Kandenko Co., Ltd.

4-8-33, Shibaura, Minato-ku, Tokyo 108-8533
}

ショナ（以下，PCS）の中にこれを防止するための各種の 保護機能が組込まれているが，集中連系時にはこれらの保 護機能が相互干渉し不動作となる懸念がある。しかし, 人 が居住する地域で危険な単独運転特性試験を実施する訳に はいかないため, 解析によって安全性を検証することが重 要になる。

これまで単独運転特性の解析には EMTP が多く使用され てきたが(4), PV システム数を増やすと行列計算の次数が急 速に増大し解析時間が膨大になるほか, 複雑な配電線マッ プの入力が難しいなどの問題点があった。これを解決する ため Y 法 ${ }^{(5)(6)}$ を活用することで, 500 台の PV システムを 含む配電線の単独運転特性について高速解析する手法を開 発した。

\section{2. 解析手法}

〈2・1〉 Y 法解析手法の採用 EMTP では数 $\mu$ 秒ベー スの瞬時值解析が可能であるが, 市販の PV 用 PCS におけ 
表 1 単独運転検出：能動方式モデルの概念

Table 1. Typical design of analysis model on active islanding protection.

\begin{tabular}{|c|c|}
\hline $\begin{array}{l}\text { Active } \\
\text { method }\end{array}$ & Algorithm of active methods \\
\hline $\begin{array}{l}(1) \\
\text { Reactive } \\
\text { Power } \\
\text { Variation }\end{array}$ & $\begin{array}{l}\text { Reactive power }(\mathrm{Q}) \text { is always shaken at a constant } \\
\text { period. The amplitude is increased according to the } \\
\text { change of line frequency to the average frequency. } \\
\mathrm{Y}=\mathrm{X} \cdot \exp [j\{\alpha+\beta \cdot|\mathrm{f}-\mathrm{fa}| \cdot \sin (\delta \cdot \mathrm{t}+\theta)\}] \\
\text { where; } \\
\alpha \text { : static bias of } \mathrm{Q} \text { variation }(\mathrm{Q}: \pm 7 \%) \\
\beta \text { : amplitude of } \mathrm{Q} \text { variation }(0.05[\mathrm{rad} / \mathrm{Hz}]) \\
\mathrm{fa} \text { : average of frequency, } \\
\delta \text { : velocity of phase rotation }(10.46[\mathrm{rad} / \mathrm{s}]) \\
\theta \text { : initial phase of } \mathrm{Q} \text { variation }\end{array}$ \\
\hline $\begin{array}{l}\text { (2) } \\
\text { Frequency } \\
\text { Shift }\end{array}$ & $\begin{array}{l}\text { Reactive power }(\mathrm{Q}) \text { is always shaken at a constant } \\
\text { period for the frequency shift. The amplitude is } \\
\text { increased according to the change of line frequency to } \\
\text { the average frequency. } \\
\mathrm{Y}=\mathrm{X} \cdot \exp [j\{\alpha+\beta \cdot|\mathrm{f} \cdot \mathrm{fa}| \cdot \operatorname{sign}\langle\cos (\delta \cdot \mathrm{t}+\theta)\rangle\}] \\
\text { where; } \\
\alpha \text { : static bias } \mathrm{Q} \text { for frequency shift }(0.1[\mathrm{~Hz}]) \\
\beta \text { : amplitude } \mathrm{Q} \text { for frequency shift }(10 \% /[\mathrm{s}]) \\
\text { fa: average of frequency } \\
\delta \text { : velocity of phase rotation }(0.126[\mathrm{rad} / \mathrm{s}]) \\
\theta \text { : initial phase for frequency shift }\end{array}$ \\
\hline
\end{tabular}

る単独運転検出アルゴリズムに関する調査では，単独運転 検出機能の受動方式は配電線の電圧 (実効值), 周波数, 位 相（ゼロクロス）など 1 サイクル毎の計測值をもとに単独 運転を検出している。また，能動方式は表 $1^{(4)}$ に例示する とおり，数 $100 \mathrm{~ms}$ ベースで無効電力变動や周波数シフトを 行なうが，これに必要な有効もしくは無効電力の注入制御 は 1 サイクル毎の実効值レベルの操作である。したがって, これらの解析に必ずしも瞬時值解析をべースとする EMTP を採用する必要はない。

一方，Y 法は動特性解析部分をルンゲクッタ法，系統部 分はガウス法による数值積分に基づく過渡安定度解析プロ グラムである。これは実効值をべースとする比較的緩やか な過渡現象解析に適したプログラムで, 大規模電力系統の 過渡安定度解析などに利用されている(7)。すなわち実効值 ベースの過渡現象解析手法であり, 多数の PV システムを 含む配電線における単独運転現象の高速解析に適している。

$\langle\mathbf{2} \cdot 2\rangle$ 単独運転現象の発生メカニズム 単独運転現 象の発生メカニズムを説明するため, 単独運転解析回路の 構成を図 1 に示す。

回路は模擬系統電源, 回生負荷, 線路負荷 (RLC) を含む 模擬配電線にPV システムを連系する構成である。回生負 荷には共振回路と回転機が考えられるが，ここでは線路上 の回転機，および他種分散電源を模擬するものとして，回

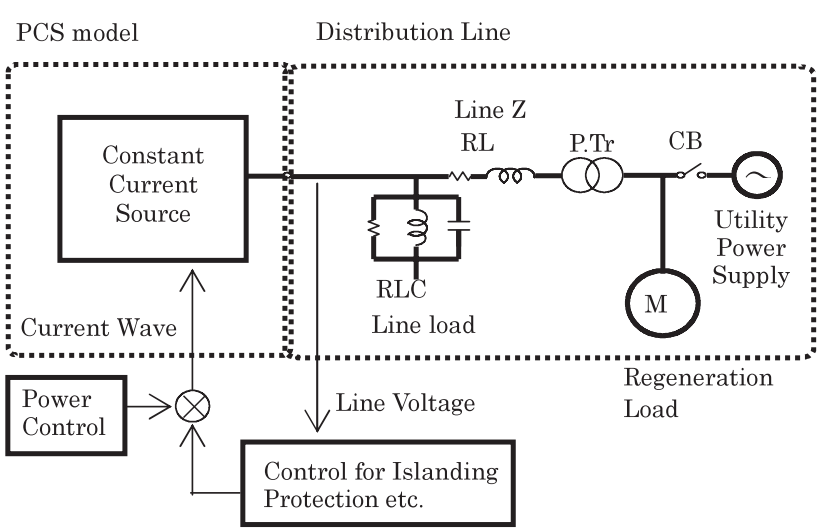

図 1 単機解析モデルの構成図

Fig. 1. Schematic diagram of single machine model for the islanding analysis.

転機（フライホイールを装着した誘導モータ）を用いてい る。なお PV 用 PCS は一般に電流源として作動する設計で ある。単独運転は上記回路において, CB 開放後に運転継 続する現象である。この現象はフライホイールに蓄積され るエネルギーを基本に, 次の (1)〜 (4) 式を用いて以下のよ うに説明できる。

$$
\begin{aligned}
& \mathrm{A}=\mathrm{I} \cdot\left(\omega_{0} \pm \omega\right)^{2} / 2 \quad[\mathrm{~J}] \\
& \mathrm{P}= \pm \mathrm{I} \cdot\left(\omega_{0} \pm \omega\right) \cdot \mathrm{d} \omega / \mathrm{dt}= \pm \mathrm{T} \cdot\left(\omega_{0} \pm \omega\right) \quad[\mathrm{W}] \\
& \omega= \pm\left(\mathrm{P} / \mathrm{T}-\omega_{0}\right) \quad[\mathrm{rad} / \mathrm{sec}]
\end{aligned}
$$

但し

$$
\mathrm{P}=\mathrm{P}_{\mathrm{PV}}-\mathrm{P}_{\mathrm{LD}} \quad[\mathrm{W}]
$$

ここに

$$
\begin{aligned}
& \mathrm{A}: \text { 蓄積エネルギー (定常状態), } \mathrm{P}: \text { 同左 (変化 } \\
& \text { 分), } \mathrm{I}: \text { 慣性モーメント, } \omega_{0}: \text { 角速度 (定常状態), } \\
& \omega: \text { 同左 (変化分), } \mathrm{T}: \text { トルク (変化分), } \mathrm{P}_{\mathrm{PV}}: \mathrm{PV} \\
& \text { 発電出力, } \mathrm{P}_{\mathrm{LD}}: \text { 線路負荷 }
\end{aligned}
$$

系統電源に連系している状態では，線路電圧と周波数は 系統電源に一致しており，(1)式に示すとおりフライホイー ルには慣性モーメント I と角速度 $\omega_{0}$ で決まる運動エネル ギー A が蓄積されている。一方，(2) 式に示すとおり系統 電源から切離されると, フライホイールの蓄積エネルギー によって線路電圧や周波数の変動が抑制される。このため PCS の単独運転検出機能の能動方式の相互干涉により検出 しにくくなる。すなわち, $\mathrm{PV}$ 発電出力 $\mathrm{P}_{\mathrm{PV}}$ のウエイトが大 きければ，フライホイールが線路から余剩エネルギー $(+\mathrm{P})$ を吸収し, 線路電圧の上昇が抑制される。このとき (3) 式か ら角速度が若干上昇する。逆に線路負荷 $\mathrm{P}_{\mathrm{LD}}$ のウエイトが 大きければ，フライホイールが不足エネルギーを放出 $(-\mathrm{P})$ し，線路電圧の低下が抑制される。このとき角速度が若干 低下する。フライホイールの慣性モーメントが大きいほど, 


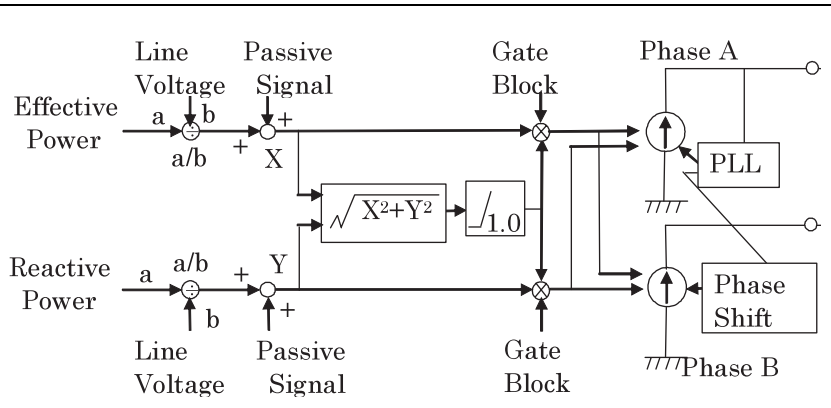

図 22 相電流源モデルの開発

Fig. 2. Development of 2 phase current sources model.

表 2 市販 PCS における単独運転検出機能の組合せ

Table 2. Combinations of the islanding protection installed in PCSs on the market.

\begin{tabular}{|c|c|c|c|}
\hline \multirow{2}{*}{$\begin{array}{c}\text { PCS } \\
\text { Model }\end{array}$} & \multirow{2}{*}{$\begin{array}{c}\text { PV } \\
\text { Output }\end{array}$} & \multicolumn{2}{|c|}{ Islanding Detection } \\
\hline & & Passive method & Active method \\
\hline $\mathrm{A}$ & $4.0 \mathrm{~kW}$ & Frequency Shift Rate & Reactive Power Variation \\
\hline $\mathrm{B}$ & $4.5 \mathrm{~kW}$ & Voltage Phase Jump & Reactive Power Variation \\
\hline $\mathrm{C}$ & $4.0 \mathrm{~kW}$ & Voltage Phase Jump & Frequency Shift. \\
\hline $\mathrm{D}$ & $3.0 \mathrm{~kW}$ & Voltage Phase Jump & Frequency Shift. \\
\hline $\mathrm{E}$ & $3.3 \mathrm{~kW}$ & Voltage Phase Jump & Frequency Shift. \\
\hline $\mathrm{F}$ & $4.0 \mathrm{~kW}$ & Frequency Shift Rate & Effective Power Variation \\
\hline \multirow{2}{*}{$\begin{array}{c}\text { G\&H } \\
\text { with } \\
\text { battery }\end{array}$} & \multirow{2}{*}{$4.0 \mathrm{~kW}$} & Voltage Phase Jump & Frequency Shift \\
\hline & & Voltage Phase Jump & Reactive Power Variation \\
\hline
\end{tabular}

線路電圧や周波数の変動が小さく抑えられ，単独運転し易 くなる。

以上は有効電力を例とした動作説明であるが, PCS が単 独運転検出のために無効電力を変動させても, フライホイー ルから逆位相の無効電力が供給されるため, 線路電圧や周波 数の変動は抑制される。以上の理論式を基に，シミュレー ション解析モデルの作成を進めた。

〈2·3〉 Y 法解析システムの改良

既存 Y 法からの改 良点をまとめると以下となる。

（1） Y 法プログラムの改良

- 三相 $\mathrm{V}$ 結線解析機能を拡張し, 単相不平衡配電回路が 取扱えるように改良した。

・パワエレ機器制御データ（Rカード領域）を拡張し， 500 台規模の PV を含むネットワークが取扱えるよう に改良。

（2）各種 PV 用 PCS モデルの開発

- 単独運転検出機能の実効值解析モデルを開発した（図 2 参照)。

上記 ( 2 ) では, 単独運転検出機能が $1 / 2$ 波周期の実効値 ベースで十分に解析可能であることを明らかにし，2 相電 流源モデルを開発するとともに，これをもとに表 2 に示す 各種の単独運転検出機能の実効值モデルを開発した。

3. シミュレーション回路の構成

〈3・1〉 PV システム単機解析モデルの構成

単独運転

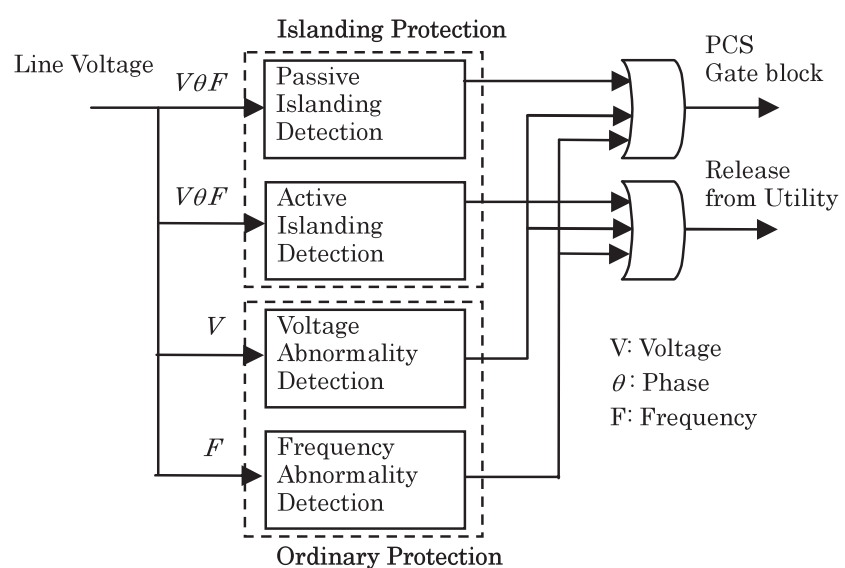

図 3 連系保護の解析モデル

Fig. 3. Analysis model of protective relaying.

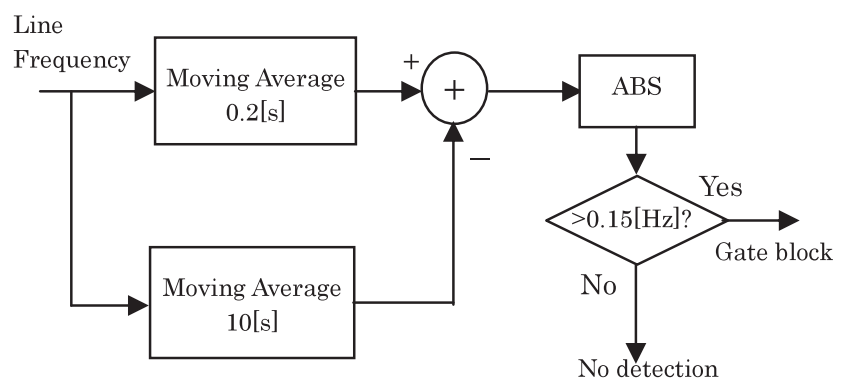

図 4 単独運転検出：受動方式モデルの例 (周波数変化率)

Fig. 4. Typical example of the model for passive islanding detection (frequency shift rate).

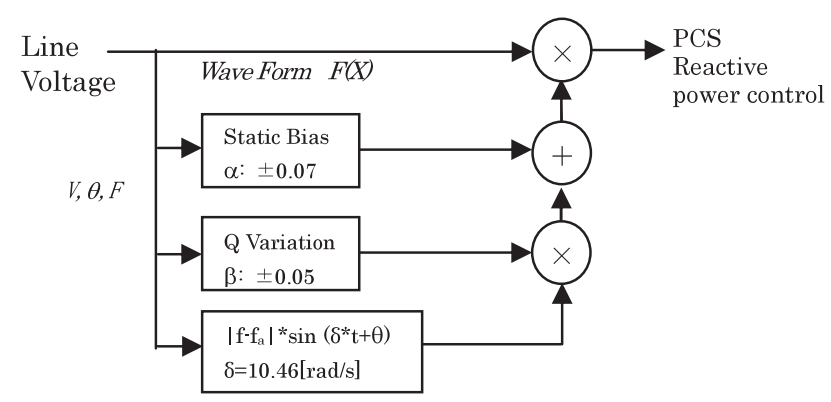

図 5 単独運転検出：能動方式モデルの例 (無効電力変動)

Fig. 5. Typical example of the model for active islanding detection (reactive power variation).

現象の単機解析モデルはPV システムを連系保護など制御 機能付きの電流源として表現しており, 先の図 1 図 2 と 同様の構成である。連系保護機能の回路構成を図 3 に示す。 連系保護回路は市販 PCS と同様に, 単独運転検出回路と配 電線異常検出回路の組合せで構成している。

このうち前者は受動方式と能動方式で構成し, 後者は電 圧異常検出と周波数異常検出で構成している。受動方式と 能動方式の回路例を図 4, 図 5 にそれぞれ示す。受動方式 では線路周波数の微小変化 (急変) を検出して PCS をゲー トブロックする。能動方式では表 1 の無効電力変動方式を 
表 3 解析で用いた実証試験地区配電系統における メーカ毎の PCS 連系台数

Table 3. Distribution of grid-connected PCSs at the demonstration site (FY2005)

\begin{tabular}{|c|c|c|c|c|c|c|}
\hline $\begin{array}{c}\text { PCS } \\
\text { model }\end{array}$ & $\begin{array}{c}3.0 \\
{[\mathrm{~kW}]}\end{array}$ & $\begin{array}{c}3.3 \\
{[\mathrm{~kW}]}\end{array}$ & $\begin{array}{c}4.0 \\
{[\mathrm{~kW}]}\end{array}$ & $\begin{array}{c}4.5 \\
{[\mathrm{~kW}]}\end{array}$ & $\begin{array}{c}5.0 \\
{[\mathrm{~kW}]}\end{array}$ & Total \\
\hline A & 10 & - & 46 & - & - & 56 \\
\hline C & - & - & 54 & - & - & 54 \\
\hline D & 18 & - & 2 & 28 & - & 48 \\
\hline E & - & 48 & - & - & 8 & 56 \\
\hline $\begin{array}{c}\text { G\&H with } \\
\text { battery }\end{array}$ & - & - & 130 & - & - & 130 \\
\hline Total & 28 & 48 & 232 & 28 & 8 & 344 \\
\hline
\end{tabular}

例にモデル化している。この例では，常時一定周期で PCS 定格容量の $\pm 7 \%$ の無効電力 $\mathrm{Q}$ を振っておき，一部の配電 線区間が系統電源から切離されたあと, 能動方式の効果で 線路周波数が変動する。

表 2 にモデル化した 8 種の受動・能動方式の組合せを示 す。これらは何れも群馬県太田市の実証試験サイト「城西 の杜」に設置されたPCS に搭載されている方式である。た だし, 方式名が同一であっても, 検出ロジックの詳細はメー カ毎に異なる。このため詳細は, 各社 PCS の仕様と出荷整 定に基づいてモデル化を行った。

$\langle 3 \cdot 2\rangle$ 多数台集中連系解析モデルの構成 実証試験 サイトにおける変電所諸元， $6.6 \mathrm{kV}$ 配電系統構成，柱上変 圧器, 低圧配電回路, 引込み線, 需要家負荷, および PV シ ステム諸元等を基に解析モデルを作成した。

また, 柱上変圧器以下の低圧配電回路では，Y 法を活用 することで多数台解析を可能とし， V 結線や単相 2 線式回 路についてプログラムデータを作成した。これを図 2 の単 機系と同様の PCS モデルを並列接続することで，PV 総数 500 台までの解析を可能とした。 $6.6 \mathrm{kV}$ 高圧系統 (3 相 3 線式）では，需要家負荷，および連系 PV システム数の違 いに基づく相間不平衡状態の単独運転解析を可能にした。 本件では表 3 に示すとおり, 総数 344 台の PV システム群 (平成 17 年度実績) を含む解析モデルを作成した。

\section{4. 解析結果}

〈4・1〉Y 法と EMTP との比較解析 Y 法による解析 手法の妥当性を検証するため, 先にく3・1 節で述べた単機 モデルを対象に，Y 法と EMTP の比較解析を行った結果を 図 6 に示す。なお，Y 法の結果を比較するために，実効值を 瞬時值に換算している。この例では計算開始から 0.5 秒で $\mathrm{CB}$ を開放し単独運転を発生させている。また，能動方式を 有効電力 $(\mathrm{P})$ 変動, 無効電力 $(\mathrm{Q})$ 変動, 周波数 $(\mathrm{F})$ シフ 卜方式とした場合の線路電圧，周波数，および PCS 出力電 流の差異はY 法と EMTP によるシミュレーションで求め, その標準偏差で評価した (表 4 参照)。その結果, $\mathrm{Y}$ 法と EMTP によるシミュレーション波形の差は標準偏差 $3 \%$ 以

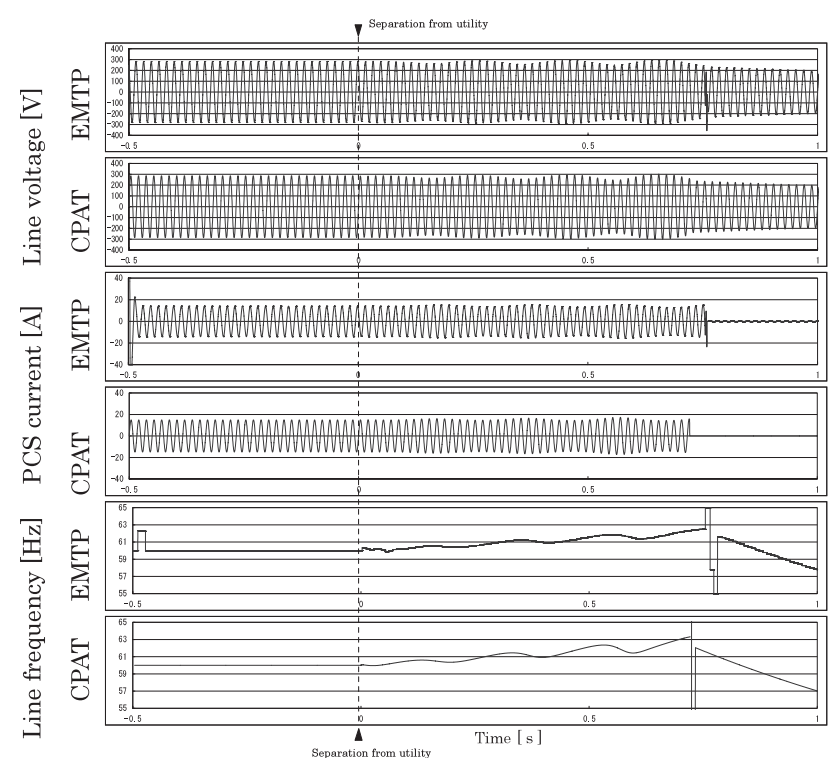

図 $6 \mathrm{Y}$ 法と EMTP の波形の比較

Fig. 6. Comparison of Y-method (CPAT) and EMTP analysis (single PV unit model).

表 $4 \mathrm{Y}$ 法と EMTP による単独運転特性解析の比較

Table 4. Comparison of the islanding analysis by CPAT (Y-method) and EMTP.

\begin{tabular}{|c|c|c|c|}
\hline & \multicolumn{3}{|c|}{ Active Islanding Protection } \\
\hline & $P$ variation & $Q$ variation & F shift \\
\hline $\begin{array}{l}\text { Difference on } \\
\qquad \text { Line Voltage } \quad[\%]^{*}\end{array}$ & 0.509 & 2.759 & 1.681 \\
\hline Line Frequency [\%]* & 1.471 & 2.114 & 0.423 \\
\hline PCS current $\quad[\%]^{\star}$ & 0.129 & 0.641 & 0.385 \\
\hline $\begin{array}{l}\text { Run on time by } \\
\text { CPAT }\end{array}$ & 1.175 & 1.215 & 1.210 \\
\hline EMTP & 1.250 & 1.255 & 1.175 \\
\hline Difference & -0.075 & -0.040 & 0.035 \\
\hline
\end{tabular}

(Notes) * : Standard Deviation for Ratings ** : Maximum Value.

\section{表 5 Y 法と EMTPによる単独運転解析手法の} 性能比較

Table 5. Comparison of performance for islanding analysis by CPAT (Y-method) and EMTP.

\begin{tabular}{|c|c|c|c|c|}
\hline & \multirow{2}{*}{$\begin{array}{c}\text { Resolution of } \\
\text { Frequency }\end{array}$} & $\begin{array}{c}\text { Number of } \\
\text { Applicable PV } \\
\text { Systems }\end{array}$ & \multicolumn{2}{|c|}{$\begin{array}{c}\text { Required Time } \\
\text { for Analysis [s] }\end{array}$} \\
\cline { 4 - 5 } & & 30 units & 500 units \\
\hline CPAT & $50 \mathrm{~Hz}$ & 500 units & 18.6 & 99.3 \\
\hline EMTP & $50 \mathrm{kHz}$ & 30 units & 25.0 & N/A \\
\hline
\end{tabular}

${ }^{*} \mathrm{PC}$ CPU: Pentium IV $1.5 \mathrm{GHz}$ RAM: 512MB

内，単独運転継続時間の差は最大 0.1 秒以内に留まること が分った。単独運転現象について検討するプログラムとし ては妥当な結果である。また，表 5 に Y 法と EMTP の時 間刻み幅と解析可能な PV システムの台数を比較して示す。

〈4・2〉 PV システム単機試験との比較解析 Y 法によ 


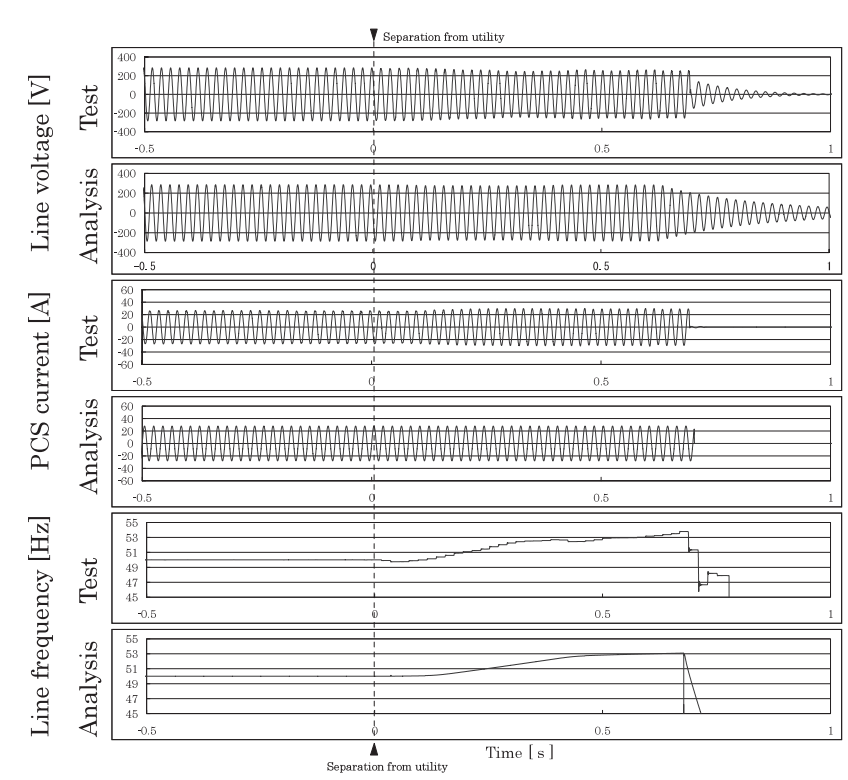

図 $7 \mathrm{Y}$ 法解析と試験結果の比較波形

Fig. 7. Comparison of wave form by Y-method (CPAT) analysis and experiment.

る解析手法の妥当性を検証するため, 実証試験サイトで使 用されている市販 PCS $(\mathrm{A} \sim \mathrm{F}$ 社) の単機試験結果との比 較評価を行なった。一例として A 社 PCS の例を図 7 に示 す。ここでは, 計算開始から 0.5 秒で系統電源を切離し, 単 独運転を発生させている。単独運転検出の能動方式は無効 電力変動方式である。解析・試験いずれも慣性モーメント は $0.3\left[\mathrm{~kg} \cdot \mathrm{m}^{2}\right], \mathrm{PV}$ 出力と線路負荷は有効・無効電力とも に平衡させた状態である。線路電圧と PCS 電流波形, およ び線路周波数の動きはよく一致している。な掞, 慣性モー メント $0.3\left[\mathrm{~kg} \cdot \mathrm{m}^{2}\right]$ は集中連系を想定するため, 一般的な単 機試験よりも若干厳しい条件設定である。

また, 前述と同じ $\mathrm{A}$ 社 PCS の事例で, PV 出力と線路負 荷の不平衡状態を有効・無効電力ともに $\pm 10 \%$ の範囲で変 化させ, 受動・能動方式の効果について整理・検討した結 果を図 8 に示す。受動・能動方式組合せ, 定格出力状態で は，同図 (a) に示すように，いずれも 0.2 秒以内に単独運 転を検出している。これに対し能動方式のみの場合は，同 図 (b)に示すと㧍り単独運転検出に要する時間が増大する 傾向を示す。一方, 単独運転検出機能が無い場合は, 同図 (c) に示すとおり単独運転検出時間が 0.5 秒を越える。同図 (d) は, 低出力で最も検出し難い事例で, ほとんどのケー スで単独運転検出時間が許容值である 1 秒を超えていた。 以上いずれも, 解析と試験の検出時間の差はほぼ 0.2 秒以 内であった。検出時間は波形の差異によるものだけではな く, 検出ロジックの判定により変わってくる。これらの比 較結果から, 解析と試験の結果は概ね一致していることが 確認できた。今後さらにこれらの差異を縮めて行く必要が あるが，PCS 内には様々な制御ループが重なり合っている ため, 両者を完全に一致させることは難しい。今後の課題 としたい。
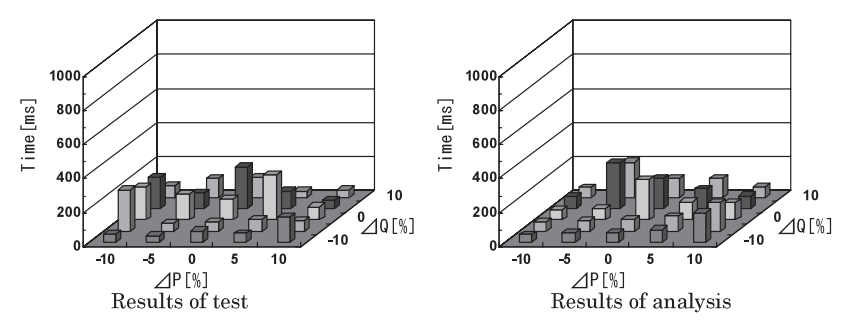

(a) Run-on time on the full islanding protection (PV output 100\%)
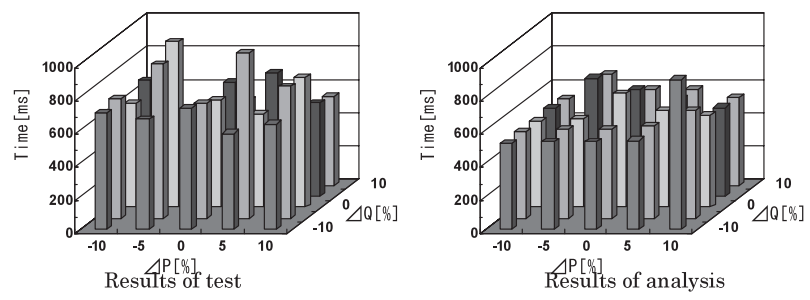

(b) Run-on time on the active islanding protection only (PV output $100 \%$ )
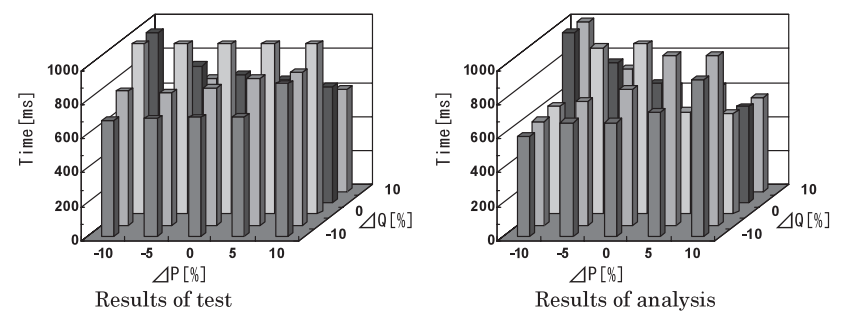

(c) Run-on time on the no islanding protection (PV output 100\%)
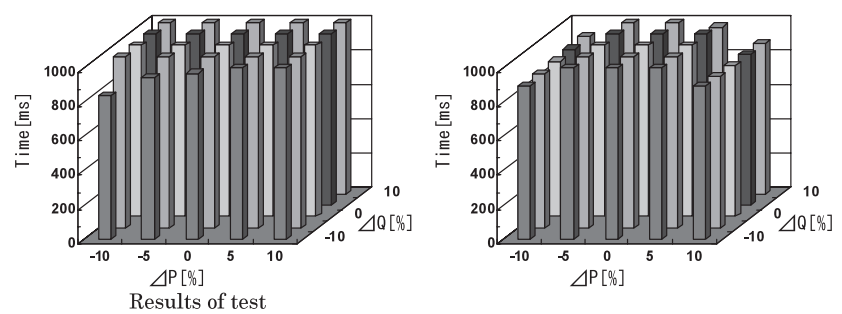

(d) Run-on time on the full islanding protection (PV output 12.5\%)

困 8 解析と試験の検出時間の比較

Fig. 8. A comparison of run-on time on the results by CPAT and experiment.

〈4·3 PV システム多数台集中連系の Y 法解析 先 に〈3.2〉節で述べた多数台集中連系解析モデルを用い, 総 数 344 台の PV システムを含む配電系統について単独運転 特性解析を実施した。PV 発電出力は定格值, 回生負荷の 慣性モーメントはPCS1 台あたりに対して $0.3\left[\mathrm{~kg} \cdot \mathrm{m}^{2}\right], \mathrm{PV}$ 出力と線路負荷は有効・無効電力ともに平衡させた状態で ある。慣性モーメントは若干厳しい条件設定である。計算 開始から 5 秒で系統電源を開放し, 単独運転状態を発生さ せた結果を図 9 に示す。(a) は能動方式における PCS 間の 位相同期あり，(b) は位相同期なしの実証試験サイト入口の 線路電圧・周波数である。

その結果, 能動方式の効果について, 能動方式の位相同 期をとれば波形が重なりあい電圧・周波数の変動量が強調 されるが，位相同期なしでは波形が打消しあい変動量が減 少することが分る。また, 各相に連系された PV システム 数が異なるため, 図 10 に示すとおり, 系統切り離し後の能 


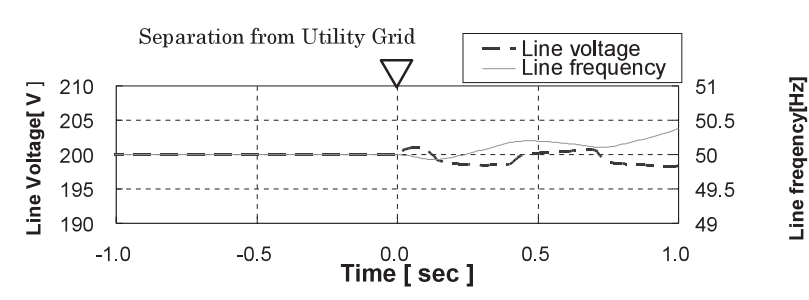

(a) Variation phase synchronized

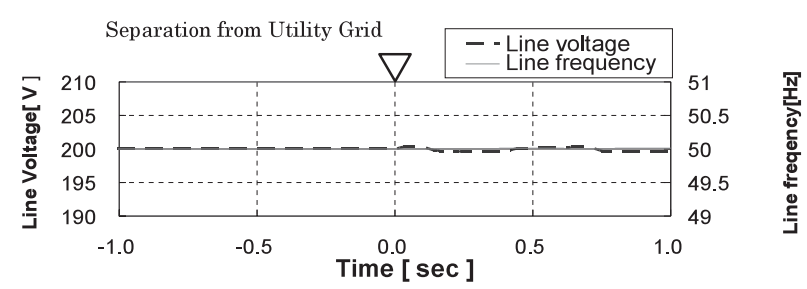

(b) Variation phase random

図 $9 \mathrm{PV}$ システム集中連系時の能動方式位相解析

Fig. 9. Effect of active islanding protection on clustered PV installation by CPAT analysis.

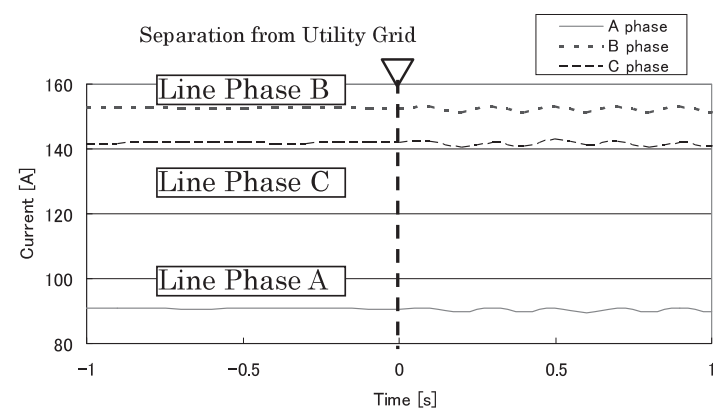

図 10 PV システム集中連系時の各相電流解析

Fig. 10. Result of clustered PV systems by CPAT.

動方式による電流変動が不平衡となっていることが分る。

解析に必要な時間はパソコンで 100 秒程度であり，様々 な単独運転現象の検討には十分な解析速度である。実際に 人が居住する実証試験サイトで危険な単独運転試験を実施 することは考えられないため，解析結果を直接的に検証す ることはできないが，さらに改良を進め，多数台集中連系 時の単独運転特性解析に活用していくものとしたい。

\section{5. まとめ}

多数の PV システムが集中連系された配電系統の安全性 解析に役立てるため, 新たにY 法による単独運転特性の多 数台・高速解析手法を開発した。新手法の妥当性を検証す るため, 従来の EMTP による単機解析結果との比較解析, およびPCSの単機性能試験結果との比較評価を行ない, 妥 当性を確認した。また，これを PV システム 500 台まで拡 張するとともに，実証試験地区城西の杜を想定した解析モ デルを作成し，総数 344 台 (平成 17 年度実績) の PV シス テムを含む配電系統の単独運転特性解析を行なった。得ら れた成果は, 今後の太陽光発電の大量導入時における安全 性評価に際し，大いに役立つものと考える。

\section{謝 辞}

本研究は NEDO 技術開発機構が推進している「集中連系
型太陽光発電システム実証研究」の一環として実施したも のである。研究の機会を与えて戴いたNEDO 各位をはじ め, $\mathrm{Y}$ 法についてご指導戴いた（財）電力中央研究所，なら びに解析計算にご協力戴いた関係各位に深く感謝したい。

(平成 18 年 7 月 26 日受付，平成 19 年 3 月 12 日再受付)

\section{文献}

（1）（株）関電工：「集中連系型太陽光発電システム実証研究」, 新エネル ギー・産業技術総合開発機構委託業務成果報告書 (2003)

（2）杉原裕征：「集中連系型太陽光発電システム実証研究の概要」, 太陽 エネルギー学会誌, Vol.30, No.6, pp.3-10 (2004)

（3）西川省吾：太陽／風力エネルギー講演論文集, pp.51-56 (2003)

（4）電力中央研究所・関西電力：「太陽光発電システム実用化技術開発 (高密度連系技術の研究) 」, 新エネルギー・産業技術総合開発機構委 託業務成果報告書 (2002)

（5）柴田秀一・宮下 茂・滝川 清・杉原裕征・大久保嘉人：「太陽光発 電システム集中連系時の単独運転検出機能の解析検討」, 太陽／風力 エネルギー講演論文集, pp.487-490 (2004)

（6）柴田秀一・滝川 清・杉原裕征：「PV システム集中連系時の単独運 転防止機能の解析一実証試験系統の解析一」, 平成 17 年電気学会電 カ・エネルギー部門大会資料, pp.31-17-31-18 (2005)

7) CRIEPI: "Integrated Analysis Software for Bulk Power System Stability", CRIEPI REPORT, ET90002 (1991)

柴 田 秀 - (正員) 1978 年 5 月 19 日生。 2003 年 3 月神奈

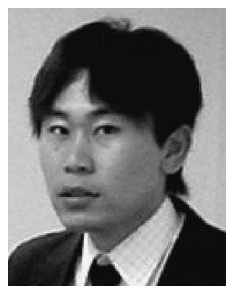
川大学大学院工学研究科電気工学専攻博士前期課 程修了。同年 4 月（株）電力テクノシステムズ入 社。現在，太陽光発電システムの研究に従事。

宮 南 一 也 (正員) 1956 年 2 月 15 日生。1 1979 年 3 月武蔵工

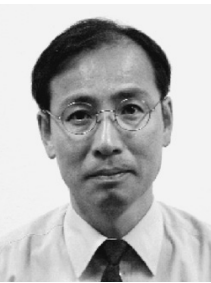
業大学工学部電気工学科卒業。2002 年より (株) 電力テクノシステムズにて省エネルギー関連の 業務に従事。現在，太陽光発電システムの研究に 従事。

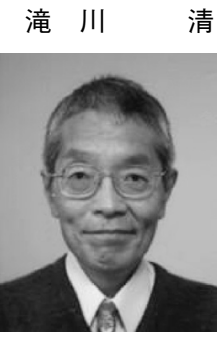

（正員） 1944 年 3 月 2 日生。1962 年，電力中央 研究所入所。2004 年より現職。当初, 電力用通信 技術の研究に従事。1978 年より太陽光発電シス テムの最適設計技術，系統連系技術，および性能 評価技術の研究に従事。系統連系技術の研究にて 1985 年オーム技術賞, 1995 年啮沢賞受賞, 1997 年電気学会論文賞受賞。

杉 原 裕 征 (正員) 1950 年 8 月 15 日生。 1976 年 3 月東京

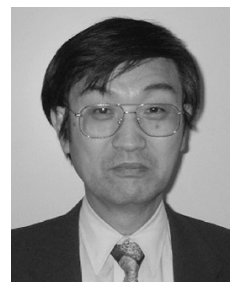
電機大学大学院丁学研究科修士浬程修了。同年 4 月（株）関電工入社。現在，技術開発本部に勤務。 主に太陽光発電システムの研究に従事。工学博士。 電気設備学会会員。 